\title{
Effects of growth hormone on pregnancy-associated murine protein-1
}

\author{
N. Fröhlander, A. A. Gidley-Baird*, J. Hau† and B. von Schoultz
}

Department of Obstetrics and Gynecology, University Hospital, S-90185 Umeä, Sweden; * Department of Veterinary Physiology, University of Sydney, New South Wales 2006, Australia; and $\dagger$ Institute of Pathology, Laboratory Animal Unit, Royal Veterinary and Agricultural University of Copenhagen, Denmark

\begin{abstract}
Summary. In male mice which normally do not synthesize measurable amounts of the pregnancy-associated murine protein-1 (PAMP-1), synthesis occurred when there was continuous infusion of hGH but not by repeated subcutaneous injections. The decrease in PAMP-1 values after hypophysectomy in female mice was rapidly restored by continuous infusion of $\mathrm{hGH}, 80 \mu \mathrm{g}$ daily. PAMP-1 has generally been regarded as an 'oestrogen-inducible' protein regulated by the oestrogen/androgen balance. Our results suggest that the apparent effects of sex steroids are mediated via the pituitary and possibly growth hormone secretion.
\end{abstract}

\section{Introduction}

Pregnancy and exogenous sex steroids greatly affect the concentration of several plasma proteins in mammals. Human 'pregnancy-zone-protein' (PZP, $\alpha_{2}-\mathrm{PAG}, \mathrm{SP}_{3}$ ) is one example of a major pregnancy-associated plasma protein with a close structural relationship to $\alpha_{2}$-macroglobulin and has proteinase binding properties (von Schoultz \& Stigbrand, 1982; Sottrup-Jensen et al., 1984). Like sex hormone binding globulin (SHBG), corticosteroid binding globulin (CBG) and ceruloplasmin, PZP is extremely sensitive to exogenous sex steroids and has been suggested as a marker of 'oestrogenicity' during clinical treatment (Damber et al., 1979; Laurell \& Rannevik, 1979). Serum concentrations increase in a strictly dose-dependent manner after oestrogen therapy and decrease after the administration of androgens, progestagens and their analogues. It would therefore seem that the synthesis of PZP should be regulated by the oestrogen/androgen balance, but several observations are at variance with this concept. After orchidectomy in men with prostatic cancer, blood concentrations of PZP were unchanged although testosterone concentrations were reduced to less than $5 \%$ of pre-treatment values (Carlström et al., 1985). In postmenopausal women treated with oral oestrogen the concentrations of SHBG, ceruloplasmin and PZP rapidly increased, whereas percutaneous administration of the same oestrogen, yielding the same concentration of circulating hormone, caused no change in protein values (Holst et al., 1983). Clearly, factors other than the steroid levels per se are involved in the regulation of protein synthesis.

An obligatory role for the pituitary gland in sex hormone action on hepatic steroid metabolism has been demonstrated in the rat. Sex differences were shown to be regulated by the secretory pattern of growth hormone and a continuous infusion of human growth hormone (hGH) had a 'feminizing' effect. Oestrogens were shown to induce a female mode of hepatic metabolism via the hypothalamo-pituitary system (Mode et al., 1981; Mode, 1983).

Mice can be used to study the regulation of pregnancy-associated proteins. The pregnancyassociated murine protein-1 (PAMP-1) is present in pregnant and non-pregnant female mice but undetectable in healthy adult male mice (Hau et al., 1982). Serum concentrations of PAMP-1 
decrease after oophorectomy but can be restored after oestrogen treatment, which seemingly indicates a sex steroid-dependent synthesis. However, hypophysectomy of female mice resulted in the disappearance of PAMP-1 from the circulation in spite of oestrogen replacement to physiological levels (Hau et al., 1983). In the present study the serum concentrations of PAMP-1 were measured in normal male and hypophysectomized female mice during administration of hGH.

\section{Materials and Methods}

Experiments were performed with outbred male and female Bom:BALB/c mice aged 8-10 weeks. Human growth hormone (hGH: Crescormon 2 i.u./ml; AB KABI, Stockholm, Sweden) was diluted in physiological saline $(9 \mathrm{~g}$ $\mathrm{NaCl} / \mathrm{l}$ ) and oestradiol-17ß in vegetable oil. Hormones were injected s.c. in volumes of 50 (4 or 8 daily injections) or $100 \mu \mathrm{l}$ ( 2 daily injections). Continuous s.c. infusion of hGH was accomplished by using an Alzet osmotic minipump (Alza Corp, Palo Alto, CA, U.S.A.) implanted s.c. in the dorsal paravertebral region of the animal. The minipumps had a filling volume of $225 \mu \mathrm{l}$ and an estimated pumping rate of $1 \mu \mathrm{l} / \mathrm{h}$ at $37^{\circ} \mathrm{C}$. Blood samples were obtained by tail-vein cut. PAMP-1 in serum was quantified by rocket immunoelectrophoresis as previously described (Hau et al., $1978,1983)$. The amount of PAMP-1 in a pool of serum from mice at $18-19$ days of gestation $(N=85)$ was assigned a value of 100 arbitrary units (AU) per $\mathrm{ml}$ and used as the master standard. The interassay coefficient of variation was $5 \%$.

Two separate experiments were performed.

Induction of PAMP-I in male mice. Male mice were divided into 6 groups of 6 mice each receiving the following therapy: (A) $50 \mu \mathrm{g} \mathrm{hGH}$ every $12 \mathrm{~h}$, (B) $25 \mu \mathrm{g} \mathrm{hGH}$ every $6 \mathrm{~h}$, (C) $12.5 \mu \mathrm{g}$ hGH every $3 \mathrm{~h}$, (D) $200 \mu \mathrm{g}$ oestradiol-17B every $12 \mathrm{~h}$, (E) $50 \mu \mathrm{g} \mathrm{hGH}$ and $200 \mu \mathrm{g}$ oestradiol-17ß every $12 \mathrm{~h}$, and (F) $80 \mu \mathrm{g} \mathrm{hGH}$ daily by continuous s.c. infusion. The different treatments were continued for 4-7 days.

Reinduction of PAMP-1 in female mice after hypophysectomy. Hypophysectomy was performed in 15 female mice according to the Bindon (1969) modification of the Lamond \& Emmens (1959) technique, under tribromoethanol anaesthesia. During a postoperative period of 7 days the animals were divided into 4 groups receiving the following therapy: (A) $10 \mu \mathrm{g} \mathrm{hGH}$ every $12 \mathrm{~h}(\mathrm{~N}=1)$, (B) $20 \mu \mathrm{g} \mathrm{hGH}$ every $12 \mathrm{~h}(\mathrm{~N}=5),(\mathrm{C}) 40 \mu \mathrm{g} \mathrm{hGH}$ every $12 \mathrm{~h}(\mathrm{~N}=4)$ and (D) $200 \mu \mathrm{l}$ saline $(9 \mathrm{~g} \mathrm{NaCl} / \mathrm{l})$ every $12 \mathrm{~h}(\mathrm{~N}=5)$. Thereafter, on the 8th post-operative day, 6 individual mice were subjected to continuous subcutaneous infusion of hGH $80 \mu \mathrm{g}$ daily for a further 1-2 weeks.

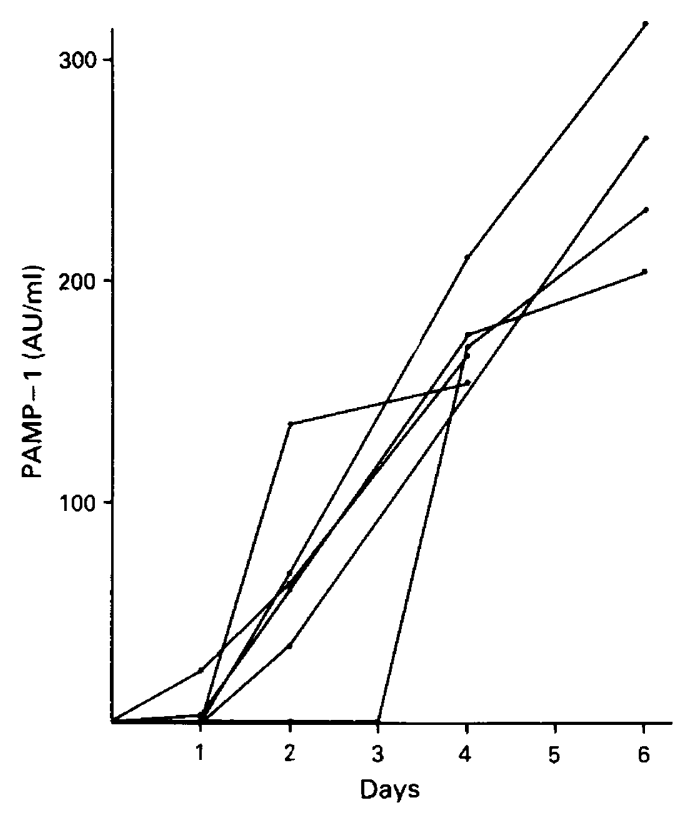

Fig. 1. Individual serum concentrations of PAMP-1 in 6 intact male mice during continuous infusion of $80 \mu \mathrm{g} \mathrm{hGH}$ daily. 


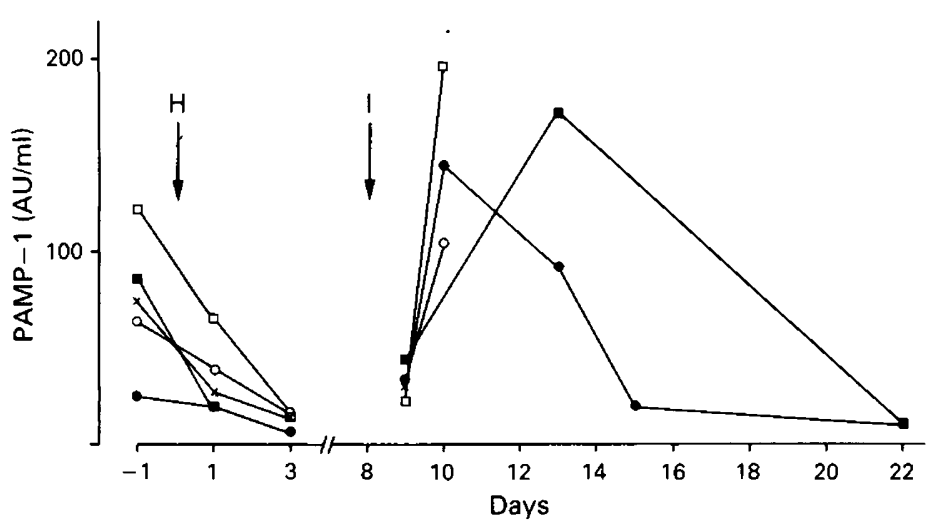

Fig. 2. Individual serum concentrations of PAMP-1 in 5 female mice before and after hypophysectomy $(\mathrm{H})$ and during continuous infusion of $80 \mu \mathrm{g} \mathrm{hGH}$ daily; I = implantation of mini-pump.

\section{Results}

Induction of PAMP-1 in male mice

Before treatment PAMP-1 was not detectable in any of the serum samples from the 36 male mice. During treatment with s.c. injections of $\mathrm{hGH}$ and oestradiol-17 $\beta$, alone or in combination, PAMP-1 was still undetectable or in a few individuals receiving different treatments at the detection limit for the assay (1-2 AU/ml). In those 6 mice that were treated with a continuous s.c. infusion of hGH there was a rapid and very pronounced increase in PAMP-1 values (Fig. 1). The mean serum concentration rose from below the detection limit of the assay to $267 \cdot 2 \mathrm{AU} / \mathrm{ml}$ (range $154-316 \mathrm{AU} / \mathrm{ml}$ ) after 4-6 days.

\section{Reinduction of PAMP-1 in female mice after hypophysectomy}

The mean pretreatment serum concentration of PAMP-1 in the 15 female mice was 105.4 AU/ml (range 18.8-190.0 AU/ml). After hypophysectomy there was a rapid decrease of PAMP-1 values in all individuals and in all groups irrespective of treatment, and after 3-5 days the mean PAMP-1 concentration was $8.7 \mathrm{AU} / \mathrm{ml}$ (range 3.8-16.0 AU/ml). Of the 6 mice that received osmotic minipumps for continuous hGH infusion 8 days after hypophysectomy, 1 mouse died before sampling. In the remaining 5 mice the PAMP-1 serum concentration rapidly increased to a mean value of $103.6 \mathrm{AU} / \mathrm{ml}$ (range 22-196 AU/ml) after 24-48 h (Fig. 2).

\section{Discussion}

The effects of exogenous sex hormones upon the serum concentrations of certain human pregnancy-associated proteins and the murine PAMP-1 are well documented but very little is known about the physiological regulation of these proteins. The values of PZP increase considerably during pregnancy, but there is no apparent correlation between the concentrations of oestrogen and protein in individual pregnant women (Westergaard et al., 1982). There is no significant variation of PZP during the menstrual cycle and concentrations are not affected by the menopause (Damber et al., 1976; Folkersen et al., 1981). Factors other than a direct influence of sex steroids are therefore likely to be involved in the regulation of PZP synthesis. Whether growth hormone is 
involved in the regulation of oestrogen-induced protein synthesis is unknown, but there are some data to support such a hypothesis. The liver is a major target organ for $\mathrm{GH}$ and oestrogen treatment has previously been shown to increase pituitary GH secretion (Wiedemann et al., 1976). The presence of GH was found to be necessary for steroid-induced protein synthesis in liver slices (Griffin \& Miller, 1974). Results from animal experiments indicate the presence of a pituitary factor, likely to be GH, that is oestrogen-sensitive and which influences liver metabolism (Mode, 1983).

The results of the present investigation can be summarized as follows. (1) In male mice, which normally do not synthesize measurable amounts of PAMP-1, synthesis of this protein was achieved by continuous infusion of $\mathrm{hGH}$ but not by s.c. injections at 3-, 6- or 12-h intervals when daily dosage was kept constant. (2) In female mice, the previously reported rapid decrease in PAMP-1 concentrations after hypophysectomy was confirmed and it could not be inhibited by injections of different amounts of hGH at 12-h intervals. On the other hand, continuous infusion of hGH, $80 \mu \mathrm{g}$ daily, rapidly restored PAMP-1 values. It may therefore be concluded that the pituitary is essential for the synthesis of PAMP-1 and possibly that the secretory pattern of a factor similar to hGH is involved in the regulation. Although heterologous hormones are valuable experimental tools (Norstedt \& Palmiter, 1984), use of xenohormones may lead to misinterpretations. In future experiments therefore, the effects of mouse $\mathrm{GH}$ on protein metabolism should be investigated. In rodents $\mathrm{hGH}$ has dual functions, being both growth-promoting and lactogenic. The effect of hGH in the present study indicates that a lactogenic, a somatogenic or a combined principle is responsible for PAMP-1 induction. The nature of the endogenous hormone causing this induction cannot be deduced. However, there is increasing evidence that the secretory pattern of GH is indeed of physiological significance as regards sexually differentiated hepatic characteristics such as protein synthesis (Jansson et al., 1985).

Whether the present results are directly applicable to the regulatory mechanism of the human PZP is unclear but the similar properties, including partial immunological identity of PAMP-1 and PZP and the location of both proteins during pregnancy on the trophoblastic surface, favours the notion that they are true analogues (Hau et al., 1981; Chemnitz et al., 1982; Hau \& Porstmann, 1984). Serum concentrations of GH have been shown to increase in a dose-dependent manner after oral administration of oestrogens to postmenopausal women, and after administration of the specific antioestrogen, tamoxifen, there was a rapid decrease in $\mathrm{GH}$ values (Fröhlander \& von Schoultz, 1986). It is tempting to speculate that growth hormone secretion is important for the regulation of 'steroid-sensitive' protein synthesis by the human liver. However, a more thorough study of this subject requires detailed investigation of the secretory patterns of GH, including its pulsatile nature and dynamic responses to various stimuli.

This work was supported by the Swedish Medical Research Council (5982). We thank Mrs M. Isaksson, Ms H. Milbo, Mrs R. Lund and Mrs M. Wallén for skilful technical assistance; Mrs M. Bergstén for excellent typing; and Mr H. I. Skovgaard-Jensen for access to his excellent facilities at the Department for Laboratory Animals, University of Copenhagen.

\section{References}

Bindon, B.M. (1969) The role of the pituitary gland in implantation in the mouse: delay of implantation of hypophysectomy and neurodepressive drugs. $J$. Endocr. 43, 225-235.

Carlström, K., Eriksson, A., Gustafsson, S.A., Henriksson, P., Pousette, Å., Stege, R. \& von Schoultz, B. (1985) Influence of orchidectomy or estrogen treatment on serum levels of pregnancy-associated $\alpha 2$-glycoprotein and sex hormone binding globulin in patients with prostatic cancer. Int. J. Androl. 8, 21-27.
Chemnitz, J., Hau, J., Svendsen, P., Folkersen, J., Westergaard, J.G. \& Christensen, B.C. (1982) Immunohistochemical demonstration of human and murine pregnancy-associated serum proteins in maternal and placental tissue. Biblthca anat. 22, 87-92

Damber, M.-G., von Schoultz, B., Stigbrand, T. \& Carlström, K. (1976) Serum levels of the pregnancy zone protein during the normal menstrual cycle. Acta obstet. gynaec. scand. 55, 467-468. 
Damber, M.-G., Sandström, B., von Schoultz, B. \& Stigbrand, T. (1979) A new sensitive method quantifying and comparing the biological potency of various estrogens in man. Acta obstet. gynaec. scand. 58, $527-530$.

Folkersen, J., Teisner, B., Grunnet, N., Grudzinskas, J.G., Westergaard, J.G. \& Hindersson, P. (1981) Circulating levels of pregnancy zone protein (PZP); normal range and the influence of age and gender. Clin. chim. Acta 110, 139-145.

Fröhlander, N. \& von Schoultz, B. (1986) Estrogen, growth hormone and pregnancy-associated proteins. In Pregnancy Proteins in Animals, pp. 83-89. Ed. J. Hau. Walter de Gruyter, Berlin.

Griffin, E.E. \& Miller, L.L. (1974) Effects of hypophysectomy of liver donors on net synthesis of specific plasma proteins by the isolated perfused rat liver. $J$. biol. Chem. 249, 5062-5069.

Hau, J. \& Porstmann, T. (1984) Characterization of the analogues to human pregnancy-associated $\alpha_{2}$-glycoprotein $\left(\alpha_{2}\right.$ PAG, PZP) isolated in the mouse and rat. Lab. Anim. 18, 344-348.

Hau, J., Svendsen, P., Teisner, B. \& Svehag, S.E. (1978) Studies of pregnancy-associated murine serum proteins. J. Reprod. Fert. 54, 239-243.

Hau, J., Westergaard, J.G., Svendsen, P., Bach, A. \& Teisner, B. (1981) Comparison of pregnancyassociated murine protein-1 and human pregnancy zone protein. J. Reprod. Immunol. 3, 341-349.

Hau, J., Svendsen, P., Teisner, B. \& Grudzinskas, J.G. (1982) Regulation of pregnancy-associated murine protein-1 by gonadal steroids. J. Reprod. Fert. 66, 273-275.

Hau, J., Gidley-Baird, A.A., Teisner, B., Svendsen, P. \& Westergaard, J.G. (1983) The influence of pituitary and gonadal hormones on serum levels of pregnancyassociated murine protein-1. Acta endocr., Copenh. 104, 23-26.

Holst, J., Cajander, S., Carlström, K., Damber, M.-G. \& von Schoultz, B. (1983) Comparison of liver protein induction in postmenopausal women during oral and percutaneous estrogen replacement therapy. $\mathrm{Br} . J$. Obstet. Gynaecol. 90, 355-360.
Jansson, J.O., Edén, S. \& Isaksson, O. (1985) Sexual dimorphism in the control of growth hormone secretion. Endocr. Rev. 6, 128-150.

Lamond, D.R. \& Emmens, C.W. (1959) The effect of hypophysectomy on the mouse uterine response to gonadotrophins. J. Endocr. 18, 251-261.

Laurell, C.B. \& Rannevik, G. (1979) A comparison of plasma protein changes induced by danazol, pregnancy and estrogens. J. clin. Endocr. Metab. 49, $719-725$.

Mode, A. (1983) Growth hormone-a regulator of the sexually differentiated steroid metabolism in rat liver. Medical doctoral thesis, Karolinska Institutet, Stockholm.

Mode, A., Norstedt, G., Simic, B., Eneroth, P. \& Gustafsson, J.A. (1981) Continuous infusion of growth hormone feminizes hepatic steroid metabolism in the rat. Endocrinology 108, 2103-2108.

Norstedt, G. \& Palmiter, R. (1984) Secretory rhythm of growth hormone regulates sexual differentiation of mouse liver. Cell 36, 805-812.

Sottrup-Jensen, L., Folkersen, J., Kristensen, T. \& Tack, B.F. (1984) Partial primary structure of human pregnancy zone protein: extensive sequence homology with human 22 -macroglobulin. Proc. natn. Acad. Sci. U.S.A. 81, 7353-7357.

von Schoultz, B. \& Stigbrand, T. (1982) Pregnancy zone protein: chemistry, biology and clinical studies. In Pregnancy Proteins, pp. 167-175. Eds J. G. Grudzinskas, B. Teisner \& M. Seppälä. Academic Press, Sydney.

Westergaard, J.G., Bach, A., Teisner, B., Hau, J. \& Grudzinskas, J.G. (1982) Circulating human pregnancy zone protein and estradiol in twin pregnancies. J. Reprod. Fert. 66, 695-698.

Wiedemann, E., Schwartz, E. \& Frantz, A.G. (1976) Acute and chronic estrogen effects upon serum somatomedin activity, growth hormone and prolactin in man. J. clin. Endocr. Metab. 42, 942-952.

Received 28 April 1986 